\title{
Folklore and literary continuum in the north caucasian novel of the late $x x$-th century in the aspect of ethnopedagogy
}

\section{El folclore y el continuo literario en la novela del norte del Cáucaso de finales del siglo xx en el aspecto de la etnopedagogía}

\author{
Arsamak Magomedovich Martazanov \\ am_martazanov@mail.ru \\ https://orcid.org/0000-0003-3718-7764 \\ Doctor of Philology, Professor of the Department "Russian and Foreign Literature" of the \\ "Ingush state University", (Magas, Russia) \\ Khanifa Magamedovna Martazanova \\ hanifa m@mail.ru \\ https://orcid.org/0000-0001-8828-3137 \\ Doctor of Philological Sciences, Professor, Head of Department "Ingush Literature and \\ Folklore" of the "Ingush state University", (Magas, Russia)

\section{Alena Mustafaevna Sarbasheva} \\ alenasarb@mail.ru \\ https://orcid.org/0000-0002-7457-9823 \\ Doctor of Philology, Head of the Sector of Karachay-Balkar Literature, Institute for \\ Humanitarian Studies-Branch of the Federal State Budgetary Scientific Institution \\ "Federal Scientific Center" Kabarda-Balkarian Scientific Center of the Russian Academy \\ of Sciences", (Nalchik, Russia)
}

Recibido: $18 / 05 / 21$

Aceptado: $07 / 07 / 21$

\begin{abstract}
The purpose of the work is to comprehend the folklore-literary continuum in the major epic works of national writers. The relevance of the research is due to the scientific and cognitive interest in folklore aesthetics, which determined the dynamics of the development of artistic thought. The novelty of the research is to study the specifics of the inseparable interaction of oral literature and literature within the chronological period of the 1960s-1990s. The main attention is projected on the novel prose of the classics of Ingush and Karachay-Balkar literature Idris Bazorkin (1910-1993) and Alim Teppeyev (1937-2010), who made a significant contribution to the development of artistic and intellectual thought of the North Caucasus region. The creative nature of the connection of these aesthetic systems contributes to the philosophical understanding of the historical events recreated by the authors in the life of an ethnic group, the comprehension of
\end{abstract}


national psychology. The appeal to the images of the Ingush and Karachay-Balkar Nart epos, folklore motives is due to the solution of the problems of the spiritual evolution of the literary hero in the context of time. The conducted research allowed us to conclude that the continuity of folklore and literature gives prose works a high aesthetic beginning, the factor of creative evolution contributes to the creation of a national picture of the world, the achievement of artistic expressiveness.

Keywords: folklore-literary continuum, Ingush literature, Karachay-Balkar literature, Nart epic, ethno-oriented learning, identity.

\section{Resumen}

El propósito del trabajo es comprender el continuo folclore-literario en las principales obras épicas de escritores nacionales. La relevancia de la investigación se debe al interés científico y cognitivo por la estética del folclore, que determinó la dinámica del desarrollo del pensamiento artístico. La novedad de la investigación es estudiar los detalles de la interacción inseparable de la literatura oral y la literatura dentro del período cronológico de las décadas de 1960 y 1990. La atención principal se proyecta sobre la prosa novedosa de los clásicos de la literatura ingush y Karachay-Balkar Idris Bazorkin (1910-1993) y Alim Teppeyev (1937-2010), quienes hicieron una contribución significativa al desarrollo del pensamiento artístico e intelectual de Región del norte del Cáucaso. La naturaleza creativa de la conexión de estos sistemas estéticos contribuye a la comprensión filosófica de los hechos históricos recreados por los autores en la vida de un grupo étnico, la comprensión de la psicología nacional. La apelación a las imágenes de los epos ingush y Karachay-Balkar Nart, motivos folclóricos se debe a la solución de los problemas de la evolución espiritual del héroe literario en el contexto del tiempo. La investigación realizada permitió concluir que la continuidad del folclore y la literatura otorga a las obras en prosa un alto inicio estético, el factor de evolución creativa contribuye a la creación de una imagen nacional del mundo, al logro de la expresividad artística.

Keywords: continuo folclore-literario, Literatura ingush, literatura Karachay-Balkar, épica nart, aprendizaje etnoorientado, identidad.

\section{Introduction}

Considering the social context as a historical condition within which the discourse of the individual functions, allows, along with the analysis of discourse as communication, to carry out the study of the extralinguistic situation of the actualization of discourse, to characterize the socio-political views of the individual, his mentality. We have taken for comparison the classics of North Caucasian literature and the Nart epic, which is significant for the preservation of the Vainakh identity. And in this case, the discursivehistorical approach seems acceptable for studying a person, his discourse in a certain cultural and historical environment. This approach is the most important in ethno-oriented teaching since it makes it possible to form a positive ethno-identity. We believe that 262 Folklore and literary continuum in the north caucasian novel of the late xx-th century in the aspect of
ethnopedagogy. - Eduweb, 2021, mayo-agosto, v.15, n.2./261-277 
positive ethno-identity plays the main role of preserving the ethnic group in the conditions of multiculturalism, globalization and blurring the boundaries of ethnic identity.

Among the urgent tasks facing the Russian literary criticism, the aspects of studying the continuity of spiritual heritage, the refraction of folklore traditions in literature in the process of its evolution are highlighted. In the works of modern North Caucasian researchers, an attempt is made to consider the problem of interaction between two aesthetic systems, to identify the spiritual and moral foundations of the artistic world of leading national writers, to study the specifics of the manifestation of the mytho-folklore worldview in their work (Dakhkilgov, 2007; Gutov, 2009; Dzhambekova, 2010; Martazanova, 2017; Sarbasheva, 2015-2017; Mamieva, 2015-2019; Martazanov, 2019).

The literature is studied from the point of view of the transformation of oral and poetic traditions, the ways of creative development of the aesthetic resources of oral literature by the authors are determined, the constructive role of folklore in the formation of artistic and stylistic features of works is noted (Guliyeva (Zanukoeva), 2015; Sarbasheva, 2019).

Native language and native culture are mandatory academic disciplines within the regional component, they form and improve communicative and professional skills, solve the problems of full-fledged linguistic and cultural development of the individual, and the possession of the native language in the period of globalization, mobility of world processes is the main guarantee of both self-realization of the individual and its positive ethno-identity.

\section{Materials and methods}

In modern conditions, the factor of ethnoidentity plays a key role in determining the vitality of an ethnic group that is in an aggressive environment of globalization, migration, and the pressure of the virtual environment of the electronic format of society, so ethnooriented learning becomes fundamental in a new type of pedagogy (Arsaliev, 2019).

At the same time, the analysis of the content of teaching the regional component of the leads to the conclusion that there is insufficient involvement in the educational the discipline of competencies, skills, abilities, knowledge of an ethno-cultural nature. In the context of changes in the ideas of Russian pedagogy about the content of education, its cultural and social function, other forms of knowledge retransmission are currently being developed, which allow us to assert that the active ethnooriented orientation of the teacher's worldview position improves the quality of teaching. At the present stage of political, cultural, and social relations, there is the primary need is to develop pedagogical conditions for ethnooriented language education at school based on the case method, including the orientation of teaching on the components of native and other cultures.

Today, all the technologies of educational practice are used as project models of the actions of participants in the educational process, so modern pedagogical technologies 
are based on a specific theoretical foundation. The register of currently relevant educational technologies is very diverse: collective, group and individual teaching methods; technology of personality-oriented education; technologies of sign contextual learning; technology gaming character; active and passive teaching methods; method of topographic projection; problem-based learning; learning with the use of IT-technologies and information innovation; integrative technology; developmental education; design methods; technology open forms of ethno-cultural technology; distance learning, etc. (Lebeaume, 2011).

The theoretical basis of the research was a set of conceptual provisions in the areas of scientific and pedagogical knowledge defined by the problems of the work, such as: the content and structure of the system of training specialists in a Russian university within the regional component; the theory of speech and intercultural communication, ethnopsycholinguistics, the main concepts, approaches and models of pedagogically oriented descriptions of language and literature for teaching purposes; the theory of creating textbooks of the native language, native literature, Russian as a foreign language.

We try to explore the folklore-literary continuum in the national novel, since it is in it that the indissoluble connection of the designated aesthetic systems is reflected with the greatest variety. To solve this problem, the work uses a set of traditional methods of analysis: typological, comparative, cultural. The appeal to the novel prose of the second half of the twentieth century is motivated by the actualization of the idea of the continuity of spiritual and moral values in the work of national writers.

Folklore and mythological models and ethnographic components introduced into the artistic structure of the works contribute to the innovative solution of various ideological and aesthetic problems. In the narrative system, they are considered "as a kind of ethnoaesthetic microunits, in which poetic, emotional, philosophical, socio-psychological information about the spiritual and material culture of the people is presented" (Dalgat, 1975: 233).

The folklore-literary continuum is marked in the works of Balkarian, Karachai, Kabardian, Ingush, Chechen, and other authors, who were faced with a difficult task - "to fuse, combine, organically merge their own folklore traditions with written-realistic ones, in order to obtain a new synthesis, a new aesthetic quality" (Tugov, 1988: 64). The writers managed to subordinate the traditions of oral and poetic folk art to the problem of depicting the national picture of the world in various historical periods in the life of each ethnic group:

- the period of the Caucasian War - Roman A. Aidamirov's "Long Nights" (1972);

- the revolutionary period - the novels of A. Bokov "The Sons of Beka" (1968), A. Keshokov "The Peaks do not sleep" (1970), Z. Tolgurov "The Big Dipper" (1977), A. Teppeyev "Will" (1981), S. Chakhkiev "Wolf Nights" (1969); 
- the years of the Great Patriotic War - the novels of I. Mashbash "A man is not born twice" (1968), A. Keshokov "The Broken Horseshoe" (1973), A. Teppeyeva "Heavy Millstones" (1976), I. Gadiev "Nest of Sleds" (1982), A. Bokova "Lead Rains" (1987);

- deportation - S. Chakhkiev's novels "Golden Pillars" (1990), A. Bokov's "Narrow Gates" (1991), M-S. Pliev's "Day of Sorrow" (1991), Z. Tolgurov's "Blue Tipchak" (1993), A. Teppeyev's "Sirat Bridge" (1993), etc.).

These authors act as innovators in the literary process of this period. It is the novel form that has become an artistic springboard for the effective use of folklore in literary works as a focus of universal and spiritual values (Dzhambekova, 2010:161).

\section{Discussion}

The relevance of all issues related to culture, it has now acquired an unprecedented sharpness. The interest in other cultures relates to the fact that in recent years social, political and economic upheavals have led to an unprecedented migration of peoples, their resettlement, resettlement, collision, mixing, which, of course, leads to a conflict of cultures. At the same time, scientific and technological progress, and the efforts of a reasonable and peace-loving part of humanity are opening up new opportunities, types and forms of communication, the main condition for the effectiveness of which is mutual understanding of cultures, tolerance and respect for the culture of communication partners. All this, both alarming and encouraging, has led to close attention to the problems of intercultural communication, which today means "adequate mutual understanding between two participants of a communicative act belonging to different national cultures" (Vereshchagin, 1990: 26). Intercultural communication is a process of direct interaction of cultures (dialogue of cultures), which is carried out within the framework of different national stereotypes of thinking and communicative behavior, which affects mutual understanding and relationships between the communicating parties. By communicative behavior, we understand the rules and traditions of communication implemented in communication of a particular ethno-cultural community.

The researcher V. Tugov, using the example of A. Keshokov's novel-dilogy "The Peaks do not sleep", defines a "qualitatively new character" of folklore, characteristic of the national romanistics of the period of the 1960s-1990s. According to the scientist, despite the dense saturation of this work with proverbs, sayings, aphorisms, as well as legends, parables, the influence of folklore does not affect the direct citation of monuments of oral literature, not in the student's dependence on its principles of plot - building and character development.

The deep connection with national origins is found to a greater extent in the moral and ethical spheres, in the interpretation of the hero's code of honor, in the understanding of truth and injustice (Tugov, 1988; Karabulatova, Ebzeeva, Pocheshkhov, 2017). This point of view corresponds to the idea of the Ingush scholar-folklorist I. Dakhkilgov that "the principles of selection, processing and inclusion of folklore and ethnographic realities are 
designed to perform their specific and specific aesthetic function in the context of the entire work under the pen of a skilled writer" (Dakhkilgov, 2007: 2).

The rethinking of the experience of oral literature, according to the conclusion of $A$. Musukayeva, is motivated by artistic necessity and manifests itself "in the organic embodiment of folklore motives and techniques in creativity, in the ability to combine topical problems with traditional age-old ones" (Musukayeva, 1978: 131).

And this is indisputable, since folklore accumulates the moral, ethical-aesthetic, philosophical, religious views of the people, their ideas about life and death, good and evil, the sublime and the base, the beautiful and the ugly, as well as about the meaning of human life, its role and purpose in the world (Galiullina et al., 2018; Gucheti, 2019; Kipchatova, 2020; Khachmafova et all, 2017; Nijiati et al, 2020; Baltabayeva et al, 2020).

At different stages of the development of written literature, oral folk art passes in its interaction the path "from direct copying or borrowing of plots or themes to a deep artistic reinterpretation of folklore, enriching and supplementing literature spiritually" (Martazanova, 2017: 143). In the process of the evolutionary movement, independent aesthetic systems-folklore and literature-acquire a completely different qualitative character.

It is no longer "folklore that dictates its canons to literature, but the established literature begins to attract folklore to the extent that it can perform a certain function in a literary work" (Dakhkilgov, 2007: 296). The rich genre palette of folklore, themes, and motifs used due to the well-known transition of the "image into a symbol" give the artistic text "a special semantic depth and semantic perspective" (Bakhtin, 1995: 209).

The interrelation of two artistic and aesthetic systems is provable not by establishing their similarity, but by identifying their interdependence, especially since "the artistic way of knowing reality and recreating it in folklore and literature are not identical" (Bogatyrev, 1971: 369). Literary creativity, unlike folklore, is characterized by a combination of " historically determined aesthetic features, and not only by the way of cognition and recreation of reality, but also by the principles of artistic selection and typification of life phenomena, "the technique of creating a hero" (according to Gorky), a form of abstract thinking, creative individuality, the very "canonicity" of the written text" (Dalgat, 1975: 234).

The genre of the novel, which was developed in Russian literature in the 30 s of the X1 century, begins to take shape in national literatures in the twentieth century, becoming their "authorized representative", since "the free distance of the novel attracted prose writers and poets, realists and romantics" (Piskunov, 1976: 8-9). In the second half of the last century, the process of defining epic prose in the literatures of the North Caucasus region intensified. For example," When friendship is known " by S.-B. Arsanov," From the darkness of centuries " by I. Bazorkin," In the gorge "by O. Etezov, "Murat" by M. Shavaeva, "The New talisman" by B. Gurtuev, "Mountain Eagles" by Zh. Zalikhanov, 
"Peaks do not sleep" by A. Keshokov, "Towards life" by E. Urumagova, "Flint Mountains" by K. Chakhkiev and many others.

The artistic canvases that tell "about the tragic fractures of history" are characterized by typological proximity and genetic similarity, interest in the problem of historicism, in the concept of man, the world, and history (Gucheti, 2019; Karabulatova et all, 2017; Baltabayeva et al, 2020). Turning to the historical fate of the people, artistically recreating it, writers strive to know more about modernity. At the same time, the image of national life is based on understanding the problem of memory, personal and national, the complex, sometimes dramatic path of peoples in the maelstrom of historical events.

In the novel "Out of the Darkness of Centuries" (1967), the Ingush writer I. Bazorkin "synthesized the experience of world novelistics with the aesthetics of the national epic, creating a new artistic fusion in which the polyphony of the plot structure enriched the characteristic features of the oral folk epic" (Petrosyan, 1974: 348). Other researchers see here the artistically elaborated ethnotrauma of the Ingush people as an opposition of Light and Darkness (Karabulatova, Ebzeeva, Pocheshkhov, 2017).

It should be noted that the use of mythologies in artistic discourse is associated with fragments of the mythos (Razdiakonova, 2010) of the peoples of the North Caucasus. The interest in these reinterpreted myths is becoming more relevant now because of the various strategies in managing the public consciousness (Barabash et all, 2019).

When a person goes beyond his usual world, he also loses the established ties with society. This fact causes stress reactions in the form of aggression, depressive states, and frustrations. In search of his own inner self, such an individual grabs any fragments of the former mythological picture of the world (Karabulatova et all, 2017; Khachmafova et all, 2017; Baltabayeva et al, 2020).

Such fragments are defined by E. V. Razdiakonova, following R. May, a mythos, which is understood as a fragment of a myth (or the myth itself completely), which has absorbed idealized attitudes of the meaning of life (Razdiakonova, 2010). For example, the civilizational stress caused by the Caucasian military companies revealed the need to use the concepts of the traditional picture of the world for the formation of fortitude and selfidentity among the population and the introduction of the psychological attitude "everything is under control". At the same time, everything related to the clash of civilizations was published using myths about death and darkness.

In the title of the novel, the main theme is stated in a" condensed form", which determines the main plot lines and the nature of the conflict. The artistic experience of Russian realistic literature and the writer's knowledge of the oral and poetic creativity of the Ingush people affected its creation, which, in principle, was a qualitatively new word that laid the foundation for novel prose penetrating into the essence of historical processes. 
The multi-layered artistic epic about the people reveals its psychological and ideological aspects, the spiritual world, philosophical reflections on the essence of the universe, life and death, truth and lies, joy and suffering, personality and society, freedom and necessity, happiness and misery, war, and peace.

\section{Results}

Folklore and literature of the peoples of the North Caucasus abounds in background vocabulary.

The North Caucasian novelistic prose was a continuation of the epic traditions of the people, which was a natural phenomenon, because in narrative genres, primarily in the heroic epic, national traditions of artistic development of the historical life of the people were accumulated (Bayramukova, 2015). Bazorkin leads to the idea of the responsibility and moral duty of a person to the memory of his ancestors, about the inhumanity of evil and violence, about the rush to light and good of everyone.

Ethno-cultural education and education of students by means of the languages of the regional component are transmitted through the ethno-pedagogical functions of the language culture necessary for studying and teaching the language, literature, history, and culture of the peoples of the region.

\section{exchange of ethno-cultural information}

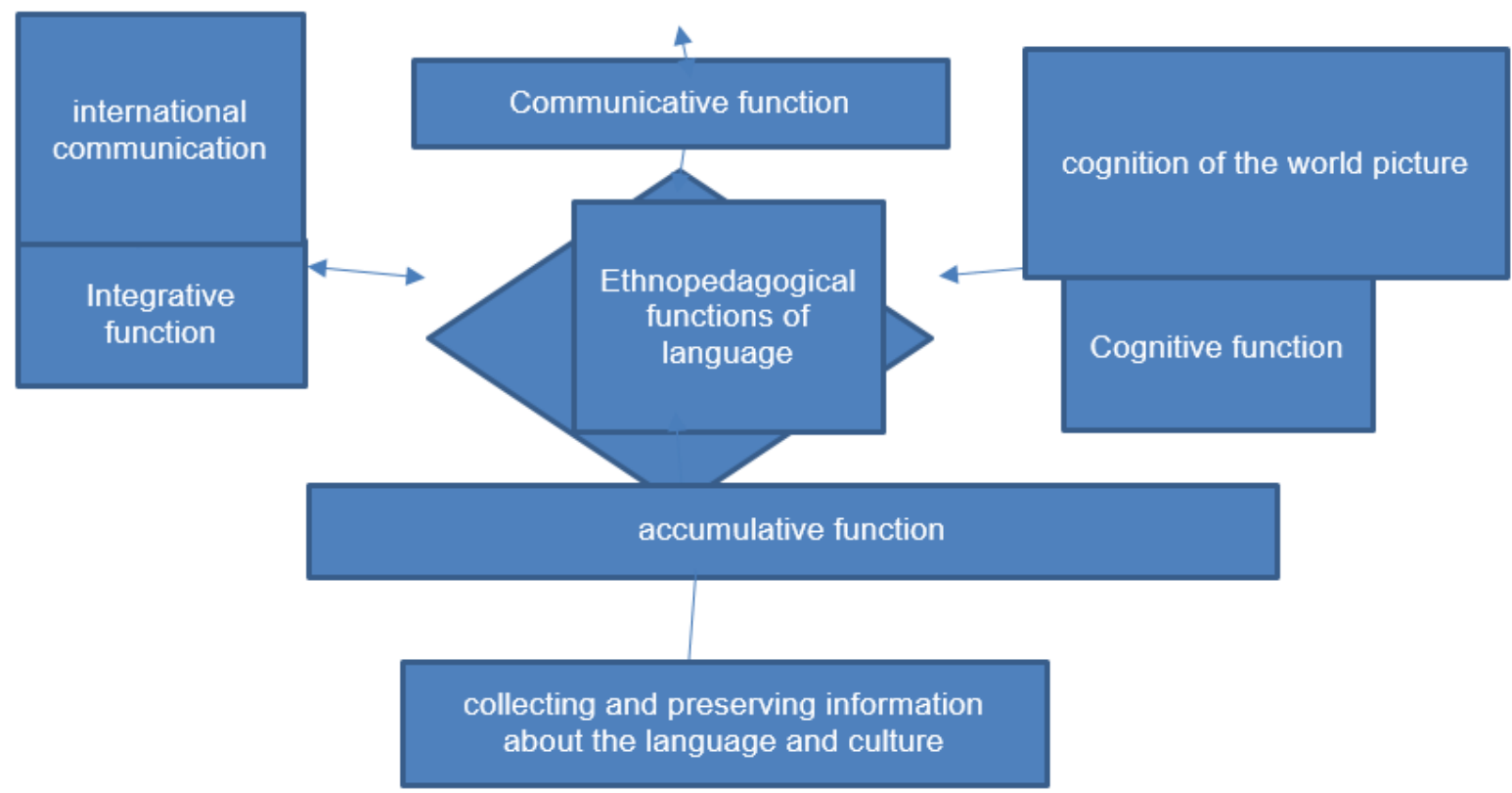

fig.1. Ethnopedagogical functions of language and literature. 
The process of language learning with etourandtravel focus, gives students not only the knowledge, abilities, and skills in all types of speech activity: listening, writing, speaking, reading, and universal educational actions, developing a personality based on the principles of tolerance, dialogue of cultures; contains pedagogical idea of providing educational impact and expressing educational functions (Sautieva, 2020).

The cultural and connotative content of words can be re-evaluated over time, which must be considered when analyzing fiction that reflects the mentality of the people, especially in a situation of ethnotrauma.

We present the ethno-cultural component as a single system of personal development: training, education by means of native culture and the culture of the studied language. We understand that by forming a cultural environment, we realize the potential of a creative, intellectually developed personality.

We also cannot imagine the effectiveness of ethno-oriented language education at school without a socio-cultural component, by which we understand the peculiarities of communication of societies, cultural values, traditions, customs. Weak consideration of the socio-cultural context was reflected by pedagogy as a factor that sharply reduces the effectiveness of teacher's professional activities (Malevinsky et all, 2019; Zamaletdinov et all, 2014).

\section{The heroes of the Nart epic in the artistic structure of the novel ("From the Darkness of Centuries" by I. Bazorkin, "Will" by A. Teppeyev)}

Writers approach the creation of a national picture of the world purely individually, because "each nation is unique and carries "genetic information" about its ethnic group, about spiritual culture, about moral content, the development of artistic thinking" (Martazanova, 2017: 24).

Consistently, without emotional intensity, I. Bazorkin introduces readers to the amazing and diverse world created by his creative genius, in which heroes live, striving for light, good, for whom nature was the cradle of freedom.

As A. Kh. Tankiev notes, in the epic, "dedicated to the image of the heroic, but difficult past of the Ingush people, folklore and ethnographic elements carry a great ideological load. The narration begins as if with the continuation of a folk epic. And in this regard, the novel, while remaining deeply realistic, is close in spirit to the folk epic" (Tankiev, 1996: $51)$.

In the prologue of the work, called the story "about how the people came out of darkness", the most complex issues of moral and philosophical content and the social situation of the Ingush people are comprehended in the context of two sections-from the spring of 1865 to January 1918. 
In the artistic world of the novel "Out of the Darkness of Centuries", all social strata of Ingush society are represented in their multifaceted connections with the foreign world. It is important for the writer to "understand the personality in the concept of history and a person, to discover the property of his character, to convey the national spirit and mentality, customs and traditions of the people" (Martazanova, 2017:151), his moral, ethical and aesthetic ideas about the world.

Idris Bazorkin turns to the fateful facts of the history of the country and the people to show how the characters of the heroes are formed in the atmosphere of original nature and difficult relationships - personal, generic (teip), national. At the same time, national folklore is used by him "when describing the hero ... and the epic interpretation of the theme itself" (Dalgat, 1981:148). Depicting the struggle of the old and the new, dying and growing, negative and positive, the writer comprehends a wide range of problems, both specifically historical and eternal, timeless: human and history, personality and people, war and peace, love and friendship, loyalty and betrayal, joy and suffering, happiness, and loss, etc. However, "the problem of becoming a national hero, which would combine both the ideal of the writer and the ideal of the people" (Martazanova, 2017: 151), is put forward as the dominant one.

The construction of the mythological space in the novel goes through the toponymic map of the myth (Kuchukova, 2015; Malevinsky, 2019). The author begins the story with a description of Egi-Kal, the ancestral tower of Egi, located surrounded by Tsey-Loma rocks, between which there are small plots of arable land, in the middle of which "a stone block rises.

Hundreds, maybe even thousands of years ago, it broke away from the mountain and froze here, halfway to the abyss, crushing an entire mountain field under it. In the old days, songs were composed about her. But time has left people only a legend that this rock was brought down in anger on his enemies by the great sled Seska-Solsa. So, it is called the rock of Seska-Solsa" (Bazorkin, 2001: 27). The sacred rock acts as the center of the universe in the mythological picture of the world of the Ingush people.

The writer thereby introduces the reader to the world of the heroic past of the Ingush, deepening and expanding it, introducing into the narrative plots widely represented in the epic heritage of the people. In particular, the legend "Kaloy-Kant and Seska-Solsa", although there is a significant layer of legends about Kaloy-Kant. According to an ancient legend, the nart Kaloy was very strong, kind, focused on good. He lived in Tsey-Lom at a time when "when robbers were sneaking around everywhere, taking away their property from peaceful people and often taking people themselves into slavery" (Nart epic of the Ingush, 2017: 495).

In the Nart epic, Kaloy-Kant is represented as a person who had extensive contacts with foreign worlds. Until the age of seven, he was supported by his older brothers, devoting a lot of time to physical exercises, developing endurance and perseverance. And only " when I felt the strength in myself, I took up work. He had a special passion for sheep 270 Folklore and literary continuum in the north caucasian novel of the late xx-th century in the aspect of
ethnopedagogy. - Eduweb, 2021, mayo-agosto, v.15, n.2./261-277 
Gduweb

Revista de Tecnología de Información y Comunicación en Educación • Volumen 15, Nㅜ 2. Mayo-agosto 2021

and therefore became a shepherd... and alone grazed his huge flock of nine hundred heads" (Nart epic of the Ingush, 2017: 492, 495). During the day, Kaloy-Kant grazed sheep, and at night he drove them into a cave, which he closed with a stone slab.

The epic antagonist of Kaloy-Kant is Seska-Solsa - "a man who was richer and stronger than anyone in all Kabarda: he could easily break a bone from a bull's leg with his hands" (Bazorkin, 2001: 97). Having learned that Kaloy-Kant is stronger than him ("no one can throw off three stones that he laid one on top of another. No one can take the baranta away from him, because it is impossible to move the slab with which he forces the entrance to the cave" (Bazorkin, 2001: 97), Seska-Solsa resorted to a trick: "he brought ... his beautiful sister to Ceylon, tore her clothes and put her on the path, as if she had fallen from a mountain" (Bazorkin, 2001: 98). In the evening, returning with his herd, Kaloy saw a girl, " picked her up and carried her to him. ... He fed the guest with meat, gave her milk to drink and put her on his bed" (Bazorkin, 2001: 98). And he sat by the fire all night. In the evening, the young man could not close the entrance to the cave: there was a gap through which a cat could " crawl, a ram could squeeze through it on the second night." At the end of the third day, Kaloy turned to the girl with the words: "A person does not stay as a guest for more than three days. Either I must take you to your house, or you must stay here as the mistress of my house" (Bazorkin, 2001: 98), and she agreed to become his wife. That evening, a person could pass through the crack into the cave, which was used by Cesca-Solsa and his retinue. They " tied his hands and feet with buffalo thongs, slaughtered his black goat, which understood human language, and ate it. And then they put out their eyes with Feces, took their girlfriend and stole the sheep" (Bazorkin, 2001: 98). The Simurkh bird helps the young man, it "sees the whole past with one eye, and the whole future with the other" (Bazorkin, 2001: 97).

According to I. Dakhkilgov, this "version, published by Ch. Akhriev in the 70s of the XIX century, the writer introduced the legends in a literary processed form into the fabric of the novel" (Dakhkilgov, 2007: 3). But according to U. Dalgat, "the author inserts fairy-tale motifs into the boy's presentation of the folk-epic tale that he tells the girl Zor": The Simurkh bird, the hen of the goddess Tusholi, living water, etc. (Dalgat, 1981: 151-152).

The main character of the novel is comparable in strength of spirit and thought to a sled, and it is named after him - Kala (Bazorkin, 2001: 68). The author traces the difficult fate of the hero, who "for the first time opened his eyes, saw not his father's shelter, but the blue sky above him" (Bazorkin, 2001: 68). As the writer shows, he inherited not only the physical strength and strength of the sled, thanks to which he stoically managed to overcome the trials that fell on his fate (Akieva, 2016; Mironenko, 2008).

The Bazorkin's hero broadcasts the qualities of a national leader. His image is associated with the strengthening of the personal principle in the novel, the understanding of the problems of "Man-World-Morality-Ethics". It is the Kaloy that acts as the moral, ethical and aesthetic ideal of its creator. 
The same tendency to use folklore plots is also visible in the work of the Karachay-Balkar writer A. Teppeyev. Thus, the novel "Azatlyk" ("Volya"/ "The Will", the year of publication is a 1986) is imbued with the spirit of historical and heroic songs, Nart legends, which determines the artistic and aesthetic guidelines of the author when creating the image of the hero and typing characters considering ethnopsychology. The folklore origin acquires a philosophical meaning in the episode in which the main character of Kanshau falls into the hands of the Belokazaks (Teppeyev, 1986: 227). The writer focuses on the folklore motif of the Karachay-Balkar song about the nart Sosruk, on the circumstances of the feats performed by distant ancestors.

Here we observe the fact of the unsuspected presence of the heroes of oral literature, which expands the epic time space in the artistic narrative. These are the central characters of the Karachay-Balkar nart legends Alaugan, Rachikau, Sosruk, etc. A narrative remark in the text of $A$. Teppeyev, using the names of heroes and characters of the mythological picture of the world of the peoples of the North Caucasus, refers us to the famous folklore text "Alaugan and Zinziuar" (Teppeyev, 1986: 39): "... Alaugan lived for a long time without a wife, and when he began to grow old, the people, cursing someone, said: "So that you, like Alaugan, grow old without a wife...."' (Narty, 1994: 401).

And here is a folklore comparison of one of the characters of the novel with another hero of the Nart epic Rachykau: "Shabaz, nicknamed Egyuz, was from the same village as Shontuk, a young wrestler, but already known in all Balkar societies... Powerful, squat, fast in movements, like Rachikau, he, despite his youth, has already become a respected person..." (Teppeyev, 1986: 114), behind which there is an episode of the fight-duel Rachykau with emegen (the legend "Nart Rachykau") - "Emegen grabbed and threw Rachykau so that he sank knee-deep into the ground. When Rachykau picked up and threw emegen, he sank into the ground up to his waist. After that, emegen threw Rachykau - and he went into the ground up to his chest. When it was Rachykau's turn, he hit emegen with all his might - and he went into the ground on the neck vertebrae [of all his seven heads] and could not get out. [Rachykau] with one blow of his sword, he took off all seven heads... " (Narty, 1994: 507). The image of another actor Battala is also revealed in comparison with the nart Sosruk ("Battala got stronger... During the festival, he was repeatedly advised to test his strength in the fight, especially the Jamauatchans wanted him to fight with the Hulamo-Bezengi hero Shabaz... If they had grabbed, maybe Battal would not have failed; although he would not have stuck his opponent up to his knees in the ground, like Sosruk Emegen's sled, but he might have been able to overcome it" (Teppeyev, 1986: 148-149), whose exploits were vividly reflected in the legend "How Sosruk fought with the Emegens" ("After [Sosruk's fight with Emegen], the sleds considered Sosruk the strongest and bravest and went to zhortuuuli only with him. And subsequently Sosruk saved the sleds from the Emegens many times... "(Narty, 1994: 380).

The ethno-cultural potential, which we consider as the ability to preserve the values of one's people, knowledge of cultural heritage, should be largely present in the content of language education. Thanks to this, the student has an idea of the "image of the world" 
or "system of knowledge about the world". This idea is transmitted through the study of the languages and culture of the region.

National writers approach the folklore riches consciously, introducing into the artistic fabric of the work those genre modifications, poetic means, plots, and images of the oral-poetic world that help solve moral, philosophical, ethical, and aesthetic problems of epochal significance.

For a modern competitive successful specialist in his professional activity, it is especially important to have oral and written communication, to be able to find, use and analyze information, and most importantly - to be able to communicate in the languages of the region and Russian, to know cultural and linguistic norms. It is such conditions that preserve the own cultural identity of the younger generation, and also allow them to master the culture of other countries and regions.

\section{Conclusion}

Generalized ethnocultural portraits of Ingush and Kabardians allow us to identify, objectively assess and justify the legitimacy of behavioral orientations of representatives of different ethnic groups of students, to adjust pedagogical strategies. Finally, the use of the proposed methods will ensure the solution of such complex regional problems of school and university practice as cognition and interpersonal communication in ethnically diverse educational groups, the prevention of conflict situations on ethnic and religious grounds, the stabilization of the overall favorable psychological climate and conditions for successful the educational process.

Thus, the archetypal basis in the North Caucasian epic prose is "characters, plots and motifs typical of Nart's legends, as well as the artistic language of the epic, its poetic musical, dramatic stylistics, yielding to the system of stylistic values."... This trend undoubtedly fits into the historical course of the evolution of art verbal art, brings ethnic originality and a unique Caucasian flavor to it" (Gutov, 2009: 130).

As can be seen from the illustrative material, the images of the heroes of A. Teppeyev's novel "Will" embody the features of the epic heroes known to the people, who possessed such qualities as strength, honor, valor. In the descriptive characterization of the characters, an artistic technique is used-a comparison with the heroes of the Nart's epic, which contributes to the disclosure of clearly expressed individual features in the appearance of a literary character.

The analysis of the novel prose of I. Bazorkin, A. Teppeyev gives grounds for the conclusion that the "ethnic gene" - the Nart epic has a tremendous impact on the aesthetic, ideological, ethical aspects of the life of the people, bringing everyone and everyone to deep philosophical reflections on the individual's involvement in the family, home, clan, the historical path of the people, maintaining ties with the past. The rejection 
of the fundamental principles of existence leads to the spiritual and moral collapse of the individual, to the national and social tragedy of ethnic groups.

A socially active personality is revealed, firstly, by phenomena of an ethno-cultural nature and behavior, secondly, by belonging to an ethnic group, and thirdly, by important value orientations. Thus, the ethno-cultural essence of a person is the basis of ethno-cultural behavior.

Familiarity with the culture and lifestyle of the region gives students socio-cultural knowledge of a certain language community.

\section{Reference}

Akieva, P. H. The history of the ancient beliefs of the Ingush (based on the material of mythology and the Nart epic). Magas: Ingush Research Institute of Humanities named after Ch. E. Akhriev; KEP, 2016, 374 p., ISBN 978-5-4482-0016-8

Arsaliev, Sh. (2019). Ethno Pedagogical Technologies in Regional Education Environment. Conference: SCTCGM 2018, Social and Cultural Transformations in the Context of Modern Globalism. DOI: 10.15405/epsbs.2019.03.02.320

Bakhtin, M.M. (1995). Literature and aesthetics. Moscow: Fiction, 504.

Baltabayeva, Z., Sautieva, F., Skorobogatova, A., \& Mamatelashvili, O. (2020). The impact of success factors on the strategic management in an educational complex. Amazonia Investiga, 9(29), 336-346. https://doi.org/10.34069/Al/2020.29.05.38

Bayramukova S. K. (2015). Typology and national identity of the historical and artistic novel (based on the material of North Caucasian literatures). Modern problems of science and education, No. 1-1. URL: http://scienceeducation.ru/ru/article/view?id=18993 (accessed: 16.07.2021).

Barabash, V., Kotelenets, E., Karabulatova, I., Lavrentyeva, M., \& Mitina, Y. (2019). The confrontation between the Eastern and Western worldviews in the conceptual space of the information war against Russia: the genesis and evolution of the terminological apparatus. Amazonia Investiga, 8(19), 246-254. Retrieved from https://amazoniainvestiga.info/index.php/amazonia/article/view/226

Bazorkin, I. (2001). M. Collected works: In 6 vols. Compiled by, introductory article, commentary by Ya. Patiev. Magas: Serdalo Publishing House, 2001, ISBN 594452-010-8

Bogatyrev, P.G. (1971). Folklore as a special form of creativity. In the book: Bogatyrev P.G. Questions of the theory of folk art. $M$. https://www.studmed.ru/view/bogatyrev-pg-voprosy-teorii-narodnogoiskusstva_4521569793b.html

Dakhilgov, I. A. (2007). My pain and pride are my native Ingushetia. Nalchik, El-Fa Publishing Center, 2007, 576 p. ISBN 978-5-88195-874-9

Dalgat, U.B. (1975). About the folklore and ethnographic context of a literary work. The role of folklore in the development of the literatures of the peoples of the USSR. Moscow: Nauka, 233-247. 
Dalgat, U. B. (1981). Literature and Folklore: Theory. aspects. Moscow: Nauka, 303 p. Dzhambekova, T. B. (2010). Folklore as a source of the Chechen prose of the XX century. Maykop: Publishing house of MSTU, 236.

Galiullina, S. D, Karabulatova, I. S, Lyusheva, S. A, llyinova, N. A, Vildanov, R. R, \& Shalagina, S. (2018). The religious component of the dynamic processes of modern political space. J. Fundam. Appl. Sci., 10(5S), pp. 1385-1394. https://jfas.info/psjfas/index.php/jfas/article/view/5112

Gucheti, A.A., Sautieva, F.B., Bekhoeva, A.A., Musukayev, V.M., \& Misakov, V.S. (2019). The formation of health in the care thinking at early ages. Revista San Gregorio, No 30, pp. 204-208.

Guliyeva (Zanukoeva) (2015). F. Kh. Karachay-Balkarian non-fairy prose and its traditions in Balkar literature / F. Kh. Guliyeva (Zanukoeva). Nalchik: Kabardanian-Balkar Institute for Humanitarian Studies, 152. ISBN 978-5-91766-105-6

Gutov, A.M. (2009). Folk epic: Tradition and modernity. Nalchik: Publishing house KBISI, 228.

Karabulatova, I. S., Ebzeeva, J. N., \& Pocheshkhov, N. A. (2017). Tolerance problems in the context of the repressed Caucasians' ethno-trauma transformation as "LIGHT" and "DARKNESS". Terra Sebus, 9, 447-459. https://www.cclbsebes.ro/docs/Sebus_9_2017/23_KARABULATOVA\%20et\%20a lii.pdf

Karabulatova, I., Vildanov, Kh., Zinchenko, A., Vasilishina, E., \& Vassilenko, A. (2017). Problems of transformation matrices modern multicultural identity of the person in the variability of the discourse of identity Electronic Information Society. Pertanika Journal of Social Science \& Humanities, 25(S),1-16.

Khachmafova, Z.R., Karabulatova, I.S., Serebryakova, S.V., Zinkovskaya, A.V., \& Ermakova, E.N. (2017). The Specifics of an Estimate discourse of gender stereotypes in small forms of Folklore in a Network Discourse of Electronic and Information society at the Beginning of 21ct Century. Pertanika Journal of Social Science \& Humanities, 25 (S), 137-150.

Kipchatova, A. V. (2020). The problem of formation of modern polyling-cultural personality in the conditions of globalization and migration, Personality \& Society. 1, 2, pp. 33-39. DOI: https://doi.org/10.46502/issn.2712-8024/2020.2.5

Kuchukova, Z.A. (2015). Karachay-Balkarian vertical. Nalchik: Elbrus, 304. ISBN: 978-57680-2683-7

Lebeaume, J. (2011). Between Technology Education and Science Education. Positioning Technology Education in the Curriculum, 75-86. doi: 10.1007/978-946091-675-5 7

Malevinsky, S. O., Sultan, Aziz, A., Karabulatova, I. S., Luchinskiy, Y. V., Fanyan, N. Y., Grushevskaya, E. S., \& Zelenskaya, V. V. (2019). Main types of values of fullnumerication words. Religación. Revista De Ciencias Sociales Y Humanidades, 4(16), 156-163

Mamieva, I.V. (2015). The function of being in the space of everyday life (novel "Flesh from the flesh" by B. Gusalov) Modern problems of science and education, 
No. 2-3, pp. 79. URL: http://science-education.ru/ru/article/view?id=23692 (date of access: 01/17/2021).

Mamieva, I. V. (2019). "Towards life" by E. Urumagova in the light of typological generality with classical samples of the family-generic novel / / Scientific dialogue. 2019. No. 6. URL: https://cyberleninka.ru/article/n/navstrechu-zhizni-e-uruymagovoy-vsvete-tipologicheskoy-obschnosti-s-klassicheskimi-obraztsami-semeynorodovogo-romana (accessed: 16.07.2021).

Martazanov, A.M. \& Martazanova, H. M. (2019). The novel "From the darkness of centuries by I. Bazorkin in the context of Ingush Romanism of the 60s of the twentieth century". Caucasus-Russia: literary roll calls of epochs. Interregional annual collection of scientific papers. Responsible editor Khushikhanov A.M. Moscow: publishing house Fiction, pp. 135-148. ISBN 978-5-280-03911-7

Martazanova, Kh. M. (2017). The concept of man and history in the prose of Idris Bazorkin. Nazran: LLC Kep, 280.

Mironenko, E. A. (2008). On the question of folklore. Bulletin of the Kemerovo State University of Culture and Arts. No. 6. URL: https://cyberleninka.ru/article/n/kvoprosu-o-folklorizme (accessed: 16.07.2021).

Musukayeva, A.Kh. (1978). Searches and accomplishments. Nalchik: Elbrus, 67.

Narty (1994). The heroic epic of the Balkars and Karachays / [Russian Academy of Sciences, Institute of World Literature named after A.M. Gorky, Kabard. Balkar. Research Institute of History, Philology and Economics; comp. R. A.-K. Ortabaeva et al. trans. of texts by T. M. Khadzhieva, R. A.-K. Ortabaeva; introductory article, pp. 8-66, comment. and the glossary of T. M. Khadzhieva]. Moscow: Nauka: Publishing house of the firm "East. lit.", 1994. 654 p.; ISBN 5-02-017455-6. (in Russ)

Nijiati, A., Karabulatova, I., Yuan, L. and Sautieva, F. (2020). Problems of cognitive distortions in cross-cultural communication when using automatic translation in the Russian Chinese dialogue. International Scientific Forum "Issues of Modern Linguistics and the Study of Foreign Languages in the Era of Artificial Intelligence (dedicated to World Science Day for Peace and Development)" (LLT Forum 2020) Volume 88, DOI https://doi.org/10.1051/shsconf/20208803004

Petrosyan, A. A. (1974) A new section of the science of literature. (Study of the experience of the development of multinational Soviet literature) / In the book. "Modern problems of literary studies and linguistics" (On the 70th anniversary of the birth of Academician Mikhail Borisovich Khrapchenko). Nauka Publishing House, Moscow. p. 345-352.

Piskunov, V. (1976). Soviet epic novel. Genre and its evolution. Moscow: Publishing house "Soviet writer"., 367.

Razdiakonova, E. V. (2010). The ontological function of myth: myth as an existential connection between "Mythos" and "Logos" News TPU, No. 6. URL: https://cyberleninka.ru/article/n/ontologicheskaya-funktsiya-mifa-mif-kakbytiynaya-svyaz-mezhdu-mifosom-i-logosom (accessed: 25.06.2021).

Sarbasheva, A.M. (2015). Folklore and ethnographic component in the artistic structure of modern Balkar drama. Bulletin of Bashkirsk. un-ta. No. 2. URL: https://cyberleninka.ru/article/n/folklorno-etnograficheskiy-komponent-v- 


\section{Geduweb}

Revista de Tecnología de Información y Comunicación en Educación • Volumen 15, № 2. Mayo-agosto 2021

hudozhestvennoy-strukture-sovremennoy-balkarskoy-dramy

(accessed: 16.07.2021).

Sarbasheva, A. M. (2017). Specificity of the interaction of Balkar literature of the 70s-80s of the twentieth century with folklore (based on the story "The sun does not set" by Alim Teppeyev). Philological sciences, 8, 1, 38-40.

Sarbasheva, A.M. (2019). Transformation of folklore traditions in Balkar literature (based on prose). Nalchik: Publishing Printing House "Print Center", 172.

Tankiev, A. H. Spiritual towers of the Ingush people. Saratov: Children's Book, 1997. 293 p. ISBN 5-8270-0190-2

Teppeyev A. (1986). Epy Will. Moskva: PH" Sovremennik", 1986, 285 s.

Teppeyev. A. (2001). Most Sirat. Nal'chik: El'brus, 2001, 488 s. ISBN 5-7680-1649-X (in Russ)

Tugov, V.B. (1988). Hero and time. Modern literary process. Hero and time. Collection of scientific works, Cherkessk, 59-90.

Vereshchagin, E. M., \& V. G. Kostomarov (1990). Language and culture: Linguistics in teaching Russian as a foreign language, 4th ed., reprint. and dop. M.: Russian language, 246.

Zamaletdinov, R.R., Karabulatova I.S., Yarmakeev I.E., \& Ermakova E.N. (2014). LinguoPropaedeutics of ethnic conflicts as a basis for stability in complex polyethnic regions. Asian Social Science, 10, 20, 164-173. 